\title{
Ocular histoplasmosis syndrome in the United Kingdom
}

\author{
ROBERT A. BRAUNSTEIN,* DAVID A. ROSEN†, AND \\ ALAN C. BIRD
}

Retinal Diagnostic Division, Department of Clinical Ophthalmology, Institute of Ophthalmology, University of London

Reid, Scherer, Herbut, and Irving (1942) noted nodules surrounded by haemorrhage in both maculae of a patient dying of systemic histoplasmosis. A relationship between a form of uveitis with specific morphological features and evidence of exposure to Histoplasma capsulatum was also suggested by Day (1949), Krause and Hopkins (I95 I), and Schlaegel (I958). Woods and Wahlen (I959) described a specific ocular complex characterized by multiple small, discrete, focal, nonpigmented or sparsely pigmented lesions or scars in the mid or peripheral fundus (Fig. I) and a "disciform" lesion in the foveal or perifoveal area with or without surrounding haemorrhage (Fig. 2). They determined that patients with these features were frequently sensitive to histoplasmin skin antigen and postulated that systemic infection with Histoplasma capsulatum was responsible for this specific ocular condition. Later investigators have added to the above complex peripapillary chorio-retinal scarring

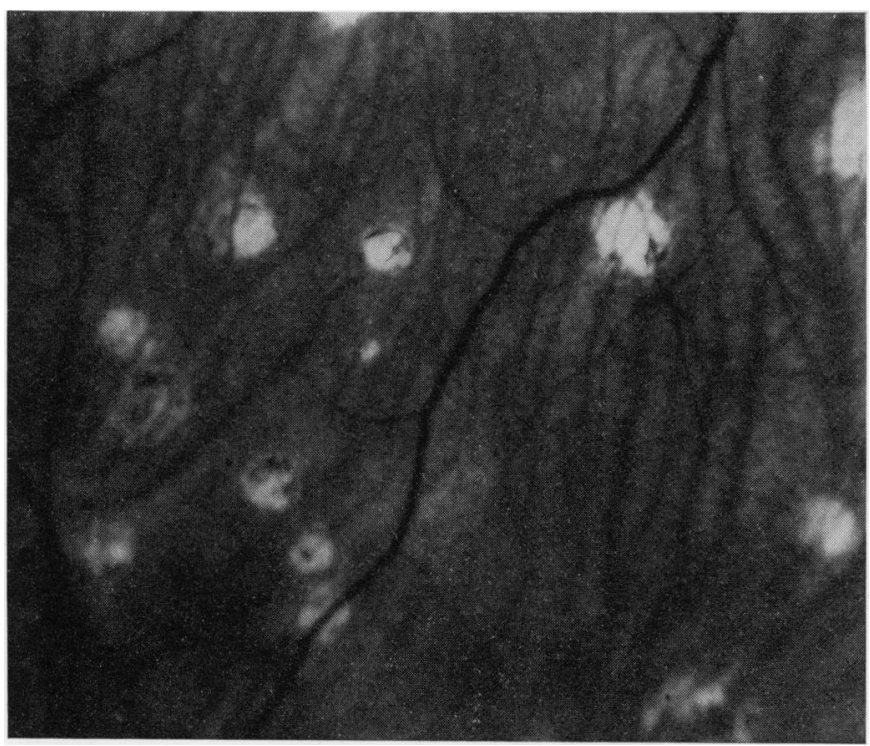

FIG. I Case 4. Red-free fundus photograph, showing peripheral atrophic pigmented and non-pigmented lesions

Address for reprints: A. C. Bird, F.R.C.S., Moorfields Eye Hospital, City Rd, London EC1V EPD * Present address: Department of Ophthalmology, Beth Israel Medical Center, 10 N.D.Perlman Place, New York, N.Y. 10003,
U.S.A.

Present address: Department of Ophthalmology, Queens University, Kingston, Ontario, Canada 


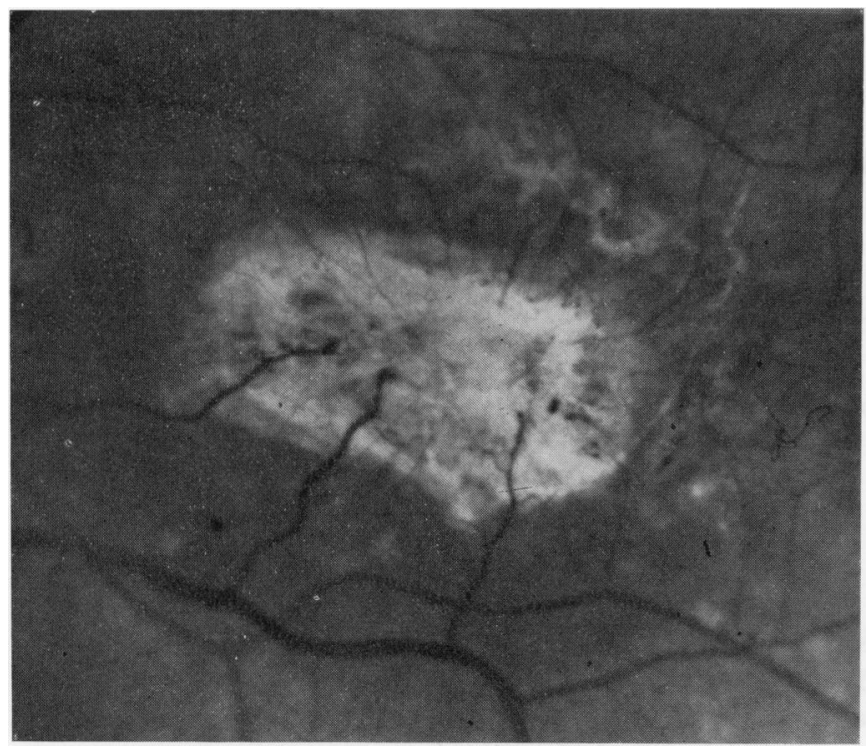

FIG. 2 Case 2. Red-free fundus photograph, showing disciform lesion with subretinal fibrotic membrane

(Schlaegel and Kenney, I966) (Fig. 3) and have emphasized the absence of vitreous or anterior segment inflammation (Van Metre and Maumenee, r964). The syndrome of "presumed ocular histoplasmosis" as currently defined is characterized by a macular disciform lesion (with or without haemorrhage), peripheral atrophic scars, peripapillary scarring, and a clear vitreous.

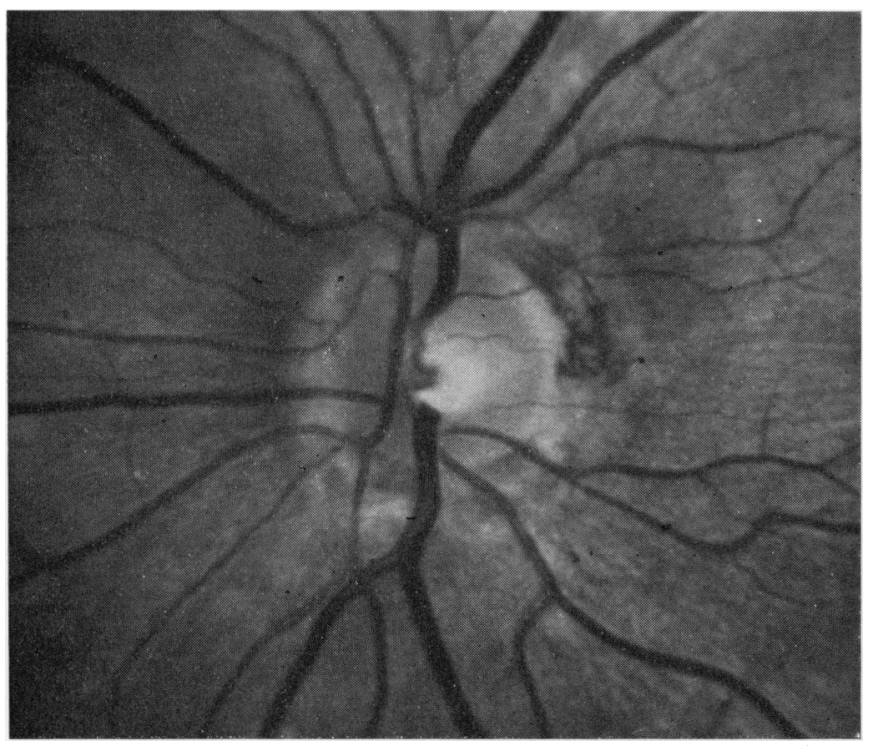

FI G. 3 Case 9. Red-free fundus photograph showing juxtapapillary chorio-retinal scarring

Most epidemiological studies of this condition have been carried out on populations in the United States where histoplasmosis is endemic. Our investigation was on patients from a population in which histoplasmosis is relatively rare (Edwards and Billings, 197 I). While most agree that ocular histoplasmosis is a distinct morphological entity, the evidence to incriminate Histoplasma capsulatum as the aetiological agent is inconclusive (Spaeth, 1967; Asbury, ı966; Makley, Long, Suie, and Stephan, I965; Giles and Falls, I96r ; Hoefnagels 
and Pijpers, I967). We intended to determine whether those with presumed ocular histoplasmosis had evidence of past or present infection with Histoplasma capsulatum.

\section{Material and methods}

Cases on the files of the Retinal Diagnostic Unit of Moorfields Eye Hospital with a diagnosis of presumed ocular histoplasmosis were reviewed and selected for recall. Each patient was examined by at least two ophthalmologists. Those accepted for the study had all of the following signs:

(I) Clear vitreous;

(2) Disciform detachment of macular or perimacular area with or without marginal subretinal haemorrhage;

(3) Small, well-defined, discrete, pigmented or sparsely pigmented choroidal lesions or scars in the central or peripheral fundus.

In addition, nine of the fifteen patients in the study had peripapillary chorio-retinal scarring

A medical social survey was taken with particular emphasis on unexplained febrile illnesses, pulmonary disease, and fungal infections. The patients were questioned to determine residence at the time of onset of symptoms of uveal tract disease and travel outside the United Kingdom before the onset.

Examinations were conducted to obtain evidence which might indicate previous infection by Histoplasma capsulatum.

\section{Skin testing}

o. I ml. I : Ioo histoplasmin* was injected intracutaneously into the volar surface of the left forearm. Reaction was read about $48 \mathrm{hrs}$ after the injection and considered positive if erythema and induration of $0.5 \mathrm{~cm}$. or more in diameter developed.

\section{Chest $x$ ray}

Postero-anterior and lateral chest $x$ rays were performed on all patients to determine the presence, if any, of fibrocalcific lesions.

\section{Serological studies}

Venous blood was analysed for complement-fixation, latex-agglutination, and immunodiffusion reactions. The blood was drawn before the implantation of the skin test because of the observation of Campbell (1960) that skin testing itself can stimulate antibody production.

\section{Results}

Skin tests, complement-fixation, latex-agglutination, and immunodiffusion reactions were negative in all patients except Case 12 who demonstrated a latex-agglutination reaction at a titre of $\mathrm{I}: 8$. All chest $x$ rays were normal. Clinical details are shown in the Table (overleaf).

\section{Discussion}

The best evidence for an association between presumed ocular histoplasmosis and infection by Histoplasma capsulatum has been derived from epidemiological studies (Schlaegel, Weber, Helveston, and Kenney, r967; Krill, Chishti, Klien, Newell, and Potts, I969; Suie, Rheins, and Makley, I965; Van Metre and Maumenee, I964; Smith and Ganley, I972). Most areas endemic for histoplasmosis lie in tropical and subtropical zones, yet the highest prevalence is

* Obtained from Parke Davis and Company, Detroit, Michigan 
Table Clinical details of fifteen patients

\begin{tabular}{|c|c|c|c|c|}
\hline Case no. & Sex & $\begin{array}{l}\text { Age } \\
(y r s)\end{array}$ & Travel outside $W$. Europe & $\begin{array}{l}\text { Peripapillary } \\
\text { scarring }\end{array}$ \\
\hline I & $\mathrm{F}$ & 35 & $\begin{array}{l}\text { Canada-resident during onset of } \\
\text { symptoms }\end{array}$ & Yes \\
\hline 2 & $\mathrm{~F}$ & 43 & No & Yes \\
\hline 3 & $\mathbf{M}$ & 40 & No & Yes \\
\hline 4 & $\mathbf{M}$ & 33 & $\begin{array}{l}\text { Africa-Asia-1o years before } \\
\text { symptoms }\end{array}$ & Yes \\
\hline 5 & $\mathbf{M}$ & 27 & No & Yes \\
\hline 6 & $\mathbf{F}$ & 40 & No & Yes \\
\hline 7 & $\mathrm{~F}$ & 70 & No & Yes \\
\hline 8 & $\mathbf{F}$ & $3^{6}$ & $\begin{array}{l}\text { U.S.A. }-6 \text { years betore } \\
\text { symptoms }\end{array}$ & Yes \\
\hline 9 & $\mathbf{F}$ & 34 & No & Yes \\
\hline Io & $\mathbf{M}$ & 46 & No & No \\
\hline I I & $\mathbf{M}$ & 46 & $\begin{array}{l}\text { Middle East—22 years before } \\
\text { symptoms }\end{array}$ & No \\
\hline 12 & $\mathrm{~F}$ & 27 & $\begin{array}{l}\text { Caribbean-3 years before } \\
\text { symptoms }\end{array}$ & No \\
\hline 13 & $\mathbf{M}$ & 29 & No & No \\
\hline 14 & $\mathbf{F}$ & 26 & No & No \\
\hline I5 & $\mathrm{F}$ & $3^{8}$ & No & No \\
\hline
\end{tabular}

in a temperate zone in the middle of the North American continent. In many localities along the Mississippi and Ohio rivers, more than 80 per cent. of the population become infected by the time they reach adulthood (Edwards, 197I). Most surveys have been carried out in the United States, where Histoplasma capsulatum is endemic. Our investigations were made on patients from a population in which Histoplasma capsulatum infection is uncommon. Indeed by 1968, only sixteen cases of systemic histoplasmosis had been reported in the United Kingdom (Knight, I968), where epidemiological studies show that only o to 2 per cent. demonstrate positive histoplasmin skin tests (Edwards and Billings, I97I). This significantly diminishes the possibility of the coincidental association of Histoplasma capsulatum infection and the ocular syndrome. Accepted criteria for the diagnosis of Histoplasma capsulatum infection include a positive reaction to the histoplasmin skin test and significant results in serological studies (complement-fixation, latex-agglutination, and immunodiffusion testsKaufman, 1971).

Since 1959, a positive correlation between histoplasmin skin reactivity and this specific syndrome has been reported (Woods and Wahlen, 1959). Between 89 and Ioo per cent. of patients with presumed ocular histoplasmosis have given positive responses to the histoplasmin skin test (Schlaegel and others, 1967; Krill and others, 1969; Suie and others, 1965; Van Metre and Maumenee, I964; Smith and Ganley, 1972). By contrast, all fifteen patients investigated in this study had negative histoplasmin skin tests.

Serological tests, complement-fixation, latex-agglutination, and immunodiffusion, provide the most widely accepted evidence for previous infection by Histoplasma capsulatum. These tests become positive within a month after infection and remain positive for varying periods of time (Kaufman, 197I). The complement-fixation test is the procedure most 
frequently used. Many patients with culturally proven histoplasmosis have titres of $\mathrm{I}: 8$ and I : 16 . Titres of $1: 32$ or greater are highly suggestive of Histoplasma capsulatum infection and are of greater diagnostic significance than lower titres (Campbell, r96o). Using both yeastphase and mycelial-phase antigen, all patients in our study were non-reactive.

The latex-agglutination test is most frequently used as an adjunct to the complementfixation test. Reactions at a titre of $\mathrm{I}: \mathrm{I} 6$ or higher may reflect active or recent disease, but may be nonspecific (Hill and Campbell, 1962). One patient in our study demonstrated a latex-agglutination reaction at a titre of $\mathrm{I}: 8$. As both her complement-fixation and immunodiffusion reactions were negative, this result was considered to be insignificant.

The immunodiffusion test using concentrated histoplasmin may be used as a supplementary or screening procedure in the serological diagnosis of histoplasmosis (Heiner, I 958). When used in coniunction with the complement-fixation test, a diagnosis of histoplasmosis was made in $9^{8}$ per cent. of culturally proven cases (Kaufman, I97 I). All fifteen patients we investigated were nonreactive in this test.

Pulmonary changes characterized by fibrocalcific lesions can be detected by chest $x$ rays and have been described in a high percentage of patients who have histoplasmosis (Silverman, I960). However, these changes are nonspecific and may result from many types of pulmonary infections (Saliba, 197I). No radiological abnormalities were found in the patients in this study.

Place of residence is an important factor in the epidemiology of histoplasmosis (Edwards, I97 I). The two patients in our study who had visited North America had negative serological tests.

In the present study of fifteen patients, all with the criteria of ocular histoplasmosis and resident in the United Kingdom, none had evidence of infection with Histoplasma capsulatum. All the patients were accepted after the unanimous approval of ophthalmologists familiar with the clinical entity as described in North America. This appears to negate the aetiological role of Histoplasma capsulatum in this syndrome in the United Kingdom. While presumed ocular histoplasmosis may be due to Histoplasma capsulatum in areas of endemic infection, no evidence was found in this study to substantiate such an association in the United Kingdom.

\section{Summary}

Fifteen patients resident in the United Kingdom with the ophthalmological criteria of ocular histoplasmosis failed to demonstrate evidence of infection with Histoplasma capsulatum.

The authors wish to acknowledge Dr. Yvonne Clayton, Brompton Hospital, London, S.W.3., for her laboratory assistance and Mr. Kulwant Sehmi, Moorfields Eye Hospital, London, E.G. I., for his photographic expertise.

\section{References}

ASBury, T. (1966) Trans. Amer. ophthal. Soc., 64, 37 I

CAMPBell, c. c. (1960) Ann. N.Y. Acad. Sci., 89, 163

DAY, R. (1949) Amer. F. Ophthal., 32, 1317

EDWARDS, P. Q. (197I) "Histoplasmin sensitivity patterns around the world" in "Histoplasmosis:

Proceedings of the Second National Conference", ed. L. Ajello, E. W. Chick, and M. L. Furcolow, pp. 97-102. Thomas, Springfield, Ill.

Pud billings, e. L. (1971) Amer. F. trop. Med. Hyg., 20, 288

GILes, C. L., and falls, H. F. (1961) Amer. F. Ophthal., 5I, 588

HEINER, D. C. (1958) Pediatrics, 22, 6 I6 
HILl, G. B., and CAMPBELl, C. C. (1962) Mycopathologia, 18, I69 HOEFNAGELS, K. L. J., and PIJPERS, P. м. (1967) Amer. F. Ophthal., 63, 7I 5

KAUFMAN, L. (197I) "Serological tests for histoplasmosis: their use and interpretation", in "Histoplasmosis: Proceedings of the Second National Conference", ed. L. Ajello, E. W. Chick, and M. L. Furcolow, pp. 321-326. Thomas, Springfield, Ill.

KNIGHT, R. K. (1968) Guy's Hosp. Rep., I 1 7, 309

KRAUSE, A. C., and HOPKINs, w. G. (195I) Amer. 7. Ophthal., 34, 564

krill, A. F., Chishti, M., klien, B. A., Newell, F. W., and potts, A. M. (I969) Trans. Amer. Acad.

Ophthal. Otolaryng., 73, 222

MAKLEY, T. A., JR., LONG, J. W., SUIE T., and STEPHAN, J. D. (1965) Ibid., 69, 443

REID, J. D., SCherer, J. H., HERBUt, P. A., and IRVing, H. (I942) F. Lab. clin. Med., 27, 419

SAliba, N. A. (197I) "Pulmonary histoplasmosis" in "Histoplasmosis: Proceedings of the Second

National Conference", ed. L. Ajello, E. W. Chick, and M. L. Furcolow, pp. 193-20I. Thomas,

Springfield, Ill.

schlaegel, T. F., JR. (1958) Trans. Amer. Acad. Ophthal. Otolaryng., 62, 81 3

- and KeNNEY, D. (1966) Amer. F. Ophthal., 62, 454

$\longrightarrow$, WEBER, J. C., HELVESTON, E., and KENNEY, D. (1967) Ibid., 63, 919

SILVERMAN, F. N. (1960) "Roentgenographic aspects of histoplasmosis" in "Histoplasmosis", ed.

H. C. Sweany, p. 337. Thomas, Springfield, Ill.

Smith, R. E., and Gareley, J. P. (1972) Arch. Ophthal. (Chicago), 87, 245

SPAETH, G. L. (1967) Ibid., 77, 4 I

SUIE, T., RHEINS, M. S., and MAKLEY, T. A., JR. (1965) Amer. J. Ophthal., 6o, I059

VAN metre, T., JR., and maumenee, A. E. (1964) Arch. Ophthal. (Chicago), 71, 314

woods, A. C., and Wahlen, H. E. (1959) Trans. Amer. ophthal. Soc., 57, 318 